\title{
Dilated intercellular spaces in subtypes of gastroesophagic reflux disease
}

\author{
J. C. Álvaro-Villegas ${ }^{1}$, S. Sobrino-Cossío ${ }^{1}$, A. Hernández-Guerrero ${ }^{1}$, J. O. Alonso-Lárraga ${ }^{1}$, \\ J. G. de-la-Mora-Levy ${ }^{1}$, A. Molina-Cruz ${ }^{2}$, H. R. Domínguez-Malagón² and J. J. Herrera-Esquivel ${ }^{3}$ \\ Services of ${ }^{1}$ Endoscopy and ${ }^{2}$ Electron Microscopy. Instituto Nacional de Cancerología. ${ }^{3}$ Service of Motility. Hospital \\ General "Dr. Manuel Gea González”. México
}

\begin{abstract}
Background: dilatation of the intercellular spaces by electron microscopy has been considered as an early morphological marker of tissue injury in gastroesophageal reflux disease. The degree of dilatation in Barrett's esophagus is currently unknown.

Objectives: to determine the frequency of dilated intercellular spaces in Barrett's esophagus.

Material and methods: cross-sectional and prospective analysis of consecutive patients with gastroesophageal reflux disease. We selected symptomatic patients $>18$ years and both sexes. Patients with recent PPI use $(<14$ days), H-2 antagonists, NSAID's or previous upper GI tract surgery were excluded. Variables included: clinical-demographic data, Carlsson-Dent score, conventional endoscopy findings, $\mathrm{pH}$-metry results (in non-erosive) and normal mucosal biopsies at 2 and $5 \mathrm{~cm}$ above the squamocolumnar junction. Dilation of intercellular spaces was measured by electron microscopy. Statistics: Chi square test with a significance level 0.05 was calculated. The following four groups were compared: a) non-erosive reflux disease $(n=14)$; b) erosive esophagitis $(n=5)$; c) Barrett's esophagus $(n=13)$; and d) healthy controls $(n=5)$.

Results: the dilation of intercellular spaces was increasingly greater from non-erosive reflux to Barret's esophagus and higher in biopsies taken at $5 \mathrm{~cm}$ than at $2 \mathrm{~cm}$ of the squamous columnar junction $(2.72 \pm 1.35$ vs. $1.71 \pm 0.48 \mu \mathrm{m})(\mathrm{p}=0.001)$. There was no difference between biopsies at 2 and $5 \mathrm{~cm}$ in the other groups
\end{abstract}

Conclusion: dilation of intercellular spaces was greater in Barrett's esophagus than in the other groups and higher at $5 \mathrm{~cm}$ from the squamocolumnar junction.

Key words: Erosive esophagitis. Barrett's esophagus. Dilated intercellular spaces. Gastroesophageal reflux disease.

Received: 04-11-09.

Accepted: 11-01-10

Correspondence: J. C. Álvaro-Villegas. San Fernando 22, Tlalpan. CP 14080 México, D.F.e-mail: jc_alvarov@hotmail.com

\section{RESUMEN}

Introducción: la dilatación de los espacios intercelulares mediante microscopia electrónica se considera un marcador morfológico temprano de daño tisular en la enfermedad por reflujo gastroesofágico. El grado de dilatación en el esófago de Barrett se desconoce actualmente.

Objetivos: determinar la frecuencia y grado de la dilatación de los espacios intercelulares en el esófago de Barrett.

Material y métodos: series de casos consecutivos con análisis transversal y prospectivo de pacientes con reflujo gastroesofágico. Criterios de selección: $>18$ años, sintomáticos, ambos sexos. Se excluyeron aquellos con ingesta de IBP, antagonistas $\mathrm{H}-2$, AINE y cirugía previa. Tomamos datos clínicos, cuestionario de CarlssonDent, endoscopia, pH-metría (no erosivos), y biopsias de la mucosa normal a 2 y $5 \mathrm{~cm}$ por encima de la unión escamo-columnar. La medición de la dilatación de los espacios intercelulares fue por microscopia electrónica. Estadística: descriptiva. Prueba de Chi-cuadrado con nivel de significancia de 0,05 . Se compararon 4 grupos: a) enfermedad por reflujo no erosiva $(n=14)$; b) esofagitis erosiva $(n=5)$; ) esófago de Barrett ( $n=13)$; y d) controles sanos $(n=5)$.

Resultados: hubo mayor dilatación de los espacios intercelulares en el esófago de Barrett $(5 \mathrm{~cm}, 2,72 \pm 1,3 \mu \mathrm{m}$ vs. $2 \mathrm{~cm}, 1,7$ $\pm 0,48 \mu \mathrm{m})(\mathrm{p}=0,001)$. Los otros grupos mostraron menor dilatación y sin diferencias entre los sitios de toma de biopsias.

Conclusión: la dilatación de los espacios intercelulares fue mayor en el esófago de Barrett predominando a los $5 \mathrm{~cm}$ de la unión escamo-columnar.

Palabras clave: Esofagitis erosiva. Esófago de Barrett. Dilatación de los espacios intercelulares. Enfermedad por reflujo gastroesofágico.

Álvaro-Villegas JC, Sobrino-Cossío S, Hernández-Guerrero A Alonso-Lárraga JO, de-la-Mora-Levy JG, Molina-Cruz A, Domínguez-Malagón HR, Herrera-Esquivel JJ. Dilated intercellular spaces in subtypes of gastroesophagic reflux disease. Rev Esp Enferm Dig 2010; 102: 302-307. 


\section{INTRODUCTION}

Gastroesophageal reflux disease (GERD) is defined as the clinical and/or histopathological sequelae of the movement of the gastroduodenal contents toward the esophagus. Diagnosis of GERD can be symptomatic, endoscopic, and by means of 24-h esophageal $\mathrm{pH}$-metry $(1,2)$.

Patients with GERD have a poor quality of life due to recurrent symptoms and are also at risk for complications due to chronic esophageal exposure to gastric contents such as erosive esophagitis (EE), peptic stricture or Barrett's esophagus (BE). These findings during endoscopy allow us to assume that they suffer from GERD. However, with a visibly normal endoscopy, 24 hour esophageal $\mathrm{pH}$-monitoring identifies subjects with non-erosive GERD (NERD) (3-5).

GERD-associated histopathological changes have been papillary elongation, eosinophilic infiltrate, and basal hyperplasia, among others. One of the main changes observed through electron microscopy is dilated intercellular spaces (DIS) (3). DIS of the esophageal epithelium is an early morphological marker of tissular lesion. It presents in $20 \%$ of asymptomatic subjects, in $75 \%$ of subjects with NERD, and in $83.6 \%$ of subjects with EE; DIS diameter ranges between 0.45 and $0.56,1.0$ and 2.2 , and 0.80 and $2.27 \mu \mathrm{m}$, respectively $(3,6,7)$.

DIS distribution is not homogeneous and can possess radial (different quadrants) or axial (SCJ) distribution. DIS is most frequent in the quadrant of the three and between 1 and $2 \mathrm{~cm}$ above the SCJ (3).

The molecular mechanism responsible for DIS is not completely understood. It has been suggested that redistribution of and changes in the protein-cell complex play an important role, and changes in normal cell metabolism are strongly associated with the presence of gastric or biliary reflux (8-12).

The objectives of our study were to know the frequency of DIS in the different populations with GERD (EE, NERD, and BE) and to determine whether DIS of the esophageal epithelium above the SCJ is related with GERD and its severity.

\section{MATERIAL AND METHODS}

We carried our a descriptive transversal study of consecutive cases in patients with clinical GERD from March to September 2008 at the Instituto Nacional de Cancerología and the Digestive Physiology Unit of the Dr. Manuel Gea González Hospital, both located in Mexico City. Selection criteria included being $>18$ years of age, both genders, clinical GERD, and written informed consent. We excluded patients from the study if they had recent ingestion $(<14$ days $)$ of proton pump inhibitors (PPI), H-2 antagonists, Non-steroidal anti-inflammatory drugs (NSAIDs), sucralfate, and hiatal surgery.

We collected clinical-demographic data, age, gender, weight, height, body mass index (BMI), and the Carls-
son-Dent self-applied symptoms questionnaire for GERD (13) (Table I). We performed conventional endoscopy (Olympus GIF-Q180Z) with biopsies of the esophageal mucosa to carry out histological diagnosis, and biopsies directed toward mucosa without macroscopic changes at 2 and at $5 \mathrm{~cm}$ above the Squamocolumnar junction (SCJ) for evaluation of DIS. According to endoscopic findings, patients were classified into four groups: I. Barrett's esophagus (BE); II. Erosive esophagitis (EE); III. Nonerosive reflux disease (NERD); and IV. Healthy controls.

The biopsies taken at 2 and $5 \mathrm{~cm}$ of the normal squamous epithelium (NSE) were processed to determine the degree of DIS by means of electron microscopy at 10,000 X (JEOL JEM-1010 model); these were conducted in automatized form by a microscope with periodic maintenance and calibration; thus, a concordance test was not warranted.

\section{Operational definition of the variables}

-Carlsson-Dent questionnaire: this is a clinical questionnaire to score the symptomatology of pyrosis and acid regurgitation; it requires a score of at least 4 points, $70 \%$ sensitivity, and $40 \%$ specificity to establish the diagnosis of reflux $(13,14)$.

-Barrett's esophagus $(B E)$ : this is the abnormal situation of normal stratified squamous esophagus by means of an intestinal-type epithelium with the presence of calciform cells $(15,16)$.

-Erosive esophagitis (EE): $\mathrm{EE}$ is inflammation of chemical origin of the distal esophagus produced through chronic contact of the mucosa and the gastric or biliary reflux. Its presence is reported in $2 \%$ of patients with reflux, and manifests itself clinically by pyrosis and regurgitation in $75 \%$ of patients (16).

-Non-erosive reflux disease (NERD): this comprises a pathological reflux of the gastric content of the esophagus in a sufficient amount to produce symptoms in the absence of distal third esophageal macroscopic lesions $(16,17)$.

-Dilated intercellular spaces (DIS): these comprise the increase of intercellular spaces of the keratinized epithelium of the esophagus. It is composed of dilation of the spaces at an intercellular distance of $>0.56 \mathrm{mi}-$ cras. It presents in $20 \%$ of asymptomatic subjects, $75 \%$ of patients with NERD, and in $83.6 \%$ of patients with EE (3).

-Control group: this group was made up of healthy subjects, asymptomatic, with negative endoscopy for lesion, without antecedents of smoking and alcoholism, with a Carlsson-Dent questionnaire score of 0 .

\section{Descriptive statistics}

For nominal variables, we employed the Chi squared test with a significance level of 0.05 . For analysis, we 
Table I. Clinical-demographic characteristics of the different groups

\begin{tabular}{|c|c|c|c|c|c|}
\hline Variables & $\begin{array}{c}B E \\
n=13\end{array}$ & $\begin{array}{c}E E \\
n=14\end{array}$ & $\begin{array}{c}\text { NERD } \\
n=5\end{array}$ & $\begin{array}{c}\text { Control } \\
n=5\end{array}$ & $p$ \\
\hline $\begin{array}{l}\text { Average age } \\
95 \% \mathrm{Cl} \\
\text { SD }\end{array}$ & $\begin{array}{c}59.8 \\
52.02-67.67 \\
11.2\end{array}$ & $\begin{array}{c}51.57 \\
43.13-60.01 \\
15.29\end{array}$ & $\begin{array}{c}49.00 \\
36.33-62.67 \\
11.9\end{array}$ & $\begin{array}{c}50.50 \\
36.71-63.29 \\
10.6\end{array}$ & 0.23 \\
\hline $\begin{array}{l}\text { Average weight } \\
95 \% \mathrm{Cl} \\
\text { SD }\end{array}$ & $\begin{array}{c}66.76 \\
60.20-73.33 \\
11.7\end{array}$ & $\begin{array}{c}64.64 \\
58.22-71.06 \\
12.77\end{array}$ & $\begin{array}{c}65.40 \\
56.15-76.65 \\
8.36\end{array}$ & $\begin{array}{c}73.40 \\
62.23-84.57 \\
5.46\end{array}$ & 0.36 \\
\hline $\begin{array}{l}\text { Average BWI } \\
95 \% \mathrm{Cl} \\
\text { SD }\end{array}$ & $\begin{array}{c}25.61 \\
23.29-27.94 \\
4.84\end{array}$ & $\begin{array}{c}25.14 \\
22.5-27.79 \\
3.97\end{array}$ & $\begin{array}{c}24.60 \\
20.59-28.61 \\
1.52\end{array}$ & $\begin{array}{c}26.00 \\
22.27-29.73 \\
0.70\end{array}$ & 0.91 \\
\hline $\begin{array}{l}\text { Average Carlsson-Dent } \\
\text { questionnaire score } \\
95 \% \mathrm{Cl} \\
\mathrm{SD}\end{array}$ & $\begin{array}{c}7.07 \\
5.19-8.90 \\
3.7\end{array}$ & $\begin{array}{c}6.57 \\
4.89-8.25 \\
2.77\end{array}$ & $\begin{array}{c}6.8 \\
3.64-9.95 \\
4.82\end{array}$ & 0 & 0.82 \\
\hline
\end{tabular}

BE: Barrett's esophagus; EE: erosive esophagitis; NERD: non-erosive reflux disease; 95\% Cl: 95\% confidence interval; SD: standard deviation; BWI: body weight index.

compared the following four groups: a) NERD, group I; b) EE, group II; c) BE, group III; and d) healthy controls, group IV.

\section{RESULTS}

There were 32 patients with GERD (13 with EB, 14 with EE, five with NERD), and five healthy controls who grouped as follows: group I $(\mathrm{BE}, \mathrm{n}=13)$ : eight males and five females, with an average age of $59.8 \pm 11.2 .3$ years (52.14-67.51 years); group II (EE, $\mathrm{n}=14$ ) five males and nine females, with an average age of $51.57 \pm 15.2$ years (range, 43.13-60.01 years); group III (NERD, $\mathrm{n}=5$ ) two males and three females, with an average age of $49.00 \pm$ 13.3 years (range, 35.33-62.67 years), and group IV (healthy controls, $\mathrm{n}=5$ ), two males and three females, with an average age of $50.50 \pm 10.6$ years (range, 36.7163.29 years).

Pyrosis was present in $11 / 13$ patients with $\mathrm{BE}$, in $12 / 14$ of patients with EE, in 5/5 of patients with NERD, and in $0 / 5$ controls with negative Carlsson-Dent questionnaire. No statistically significant differences were found among the groups for age $(p=0.26)$, weight $(p=$ $0.52)$, BWI $(\mathrm{p}=0.91)$, and the Carlsson-Dent structured questionnaire $(\mathrm{p}=0.82)$ (Table I).

Light smoking was reported in $9,4,2$, and 0 cases, respectively, and social drinking of alcohol in 4, 6, 2, and 0 cases, respectively. Endoscopy demonstrated hiatal hernia in $6 / 13$ patients with $\mathrm{BE}$, in $12 / 14$ patients with $\mathrm{EE}$, and in $1 / 5$ of patients NERD. Endoscopy provided evidence of lesions of the mucosa in the different subgroups (Fig. 1).

Patients with NERD achieved an average DeMeester classification score of $36.6 \pm 19.9 \%$ (95\% CI, 25.2248.11).

Histologically, peptic ulcer was reported in all cases of EE and NERD, and specialized intestinal metaplasia with
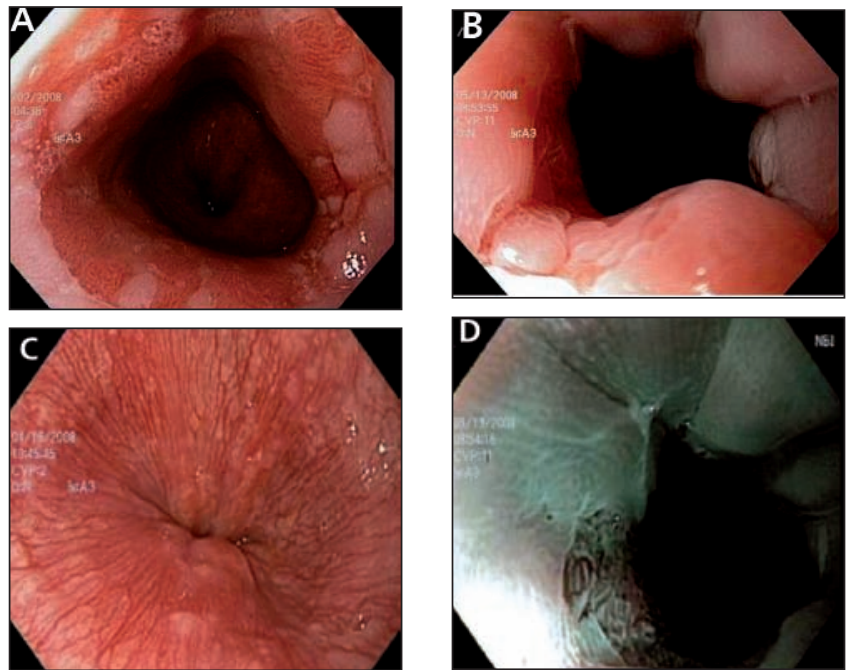

Fig. 1. A. Circumferential Barrett's esophagus. B. Short-segment Barrett's esophagus (stained with acetic acid). C. Conventional endoscopic imaging with esophageal erosions. D. Short-segment Barrett's esophagus with digital chromoscopy (narrow band imaging -NBI-).

calciform cells in cases of BE. The grades of DIS are shown in table II and figure 2. In patients with BE, we observed more DIS at $5 \mathrm{~cm}$ than at $2 \mathrm{~cm}$ of the SCJ $(2.72$ $\pm 1.35 \mu \mathrm{m} v s .1 .71 \pm 0.48 \mu \mathrm{m}(\mathrm{p}=0.001)$; on the other hand, less evidence of DIS was noted in the non-erosive and erosive varieties than in $\mathrm{BE}$, and no differences were observed among biopsy sites.

\section{DISCUSSION}

In our study, DIS was documented in all cases of GERD (erosive, non-erosive, and Barrett's esophagus). The greatest DIS was in BE, which was more at $5 \mathrm{~cm}$ 
Table II. Dilated intercellular spaces (DIS) of the two sites above the squamocolumnar epithelial junction (SCJ) in the different gastroesophageal reflux disease (GERD) groups and controls

\begin{tabular}{|c|c|c|c|c|c|}
\hline $\begin{array}{l}\text { DIS } \\
(\mu m)\end{array}$ & $B E$ & $E E$ & $N E R D$ & Control & $p$ \\
\hline $\begin{array}{l}\text { Average } 2 \mathrm{~cm} \\
95 \% \mathrm{Cl} \\
\text { SD }\end{array}$ & $\begin{array}{c}1.71 \\
1.10-2.76 \\
\pm 0.48\end{array}$ & $\begin{array}{c}1.68 \\
1.45-1.91 \\
\pm 0.35\end{array}$ & $\begin{array}{c}1.02 \\
0.58-1.47 \\
\pm 0.57\end{array}$ & $\begin{array}{c}0.61 \\
0.22-0.99 \\
\pm 0.20\end{array}$ & 0.001 \\
\hline $\begin{array}{l}\text { Average } 5 \mathrm{~cm} \\
95 \% \mathrm{Cl} \\
\text { SD }\end{array}$ & $\begin{array}{c}2.72 \\
2.08-3.11 \\
\pm 1.35\end{array}$ & $\begin{array}{c}1.97 \\
1.482 .47 \\
\pm 0.33\end{array}$ & $\begin{array}{c}1.12 \\
0.39-1.85 \\
\pm 0.41\end{array}$ & $\begin{array}{c}0.70 \\
0.12-1.52 \\
\pm 0.20\end{array}$ & 0.001 \\
\hline
\end{tabular}

BE: Barrett's esophagus; EE: erosive esophagitis; NERD: non-erosive reflux disease; $95 \%$ Cl: 95\% confidence interval; SD: standard deviation.
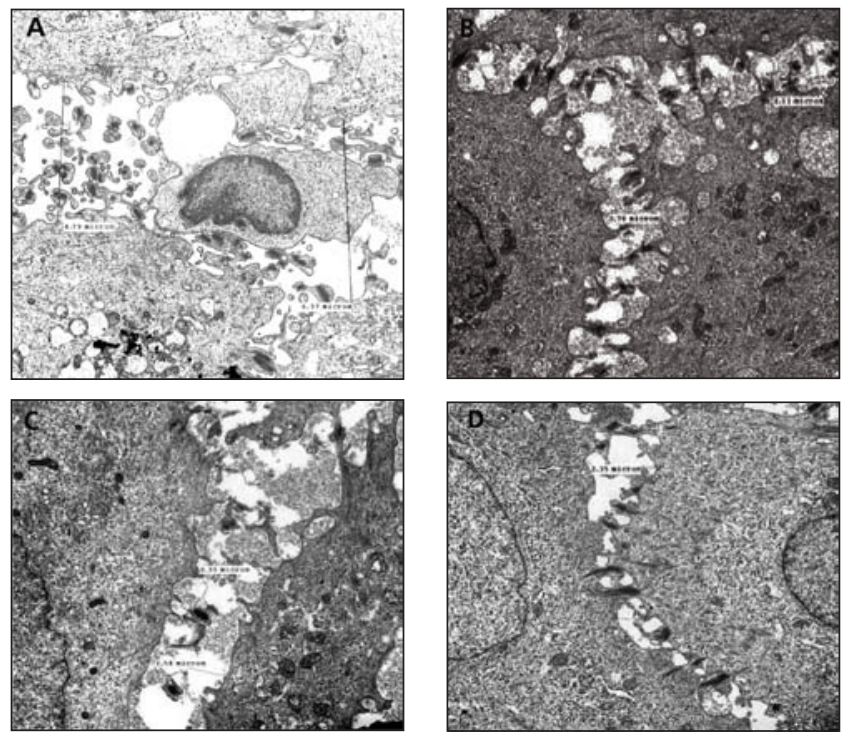

Fig. 2. Dilated intercellular spaces (DIS) in Barrett's esophagus (BE) at 5 $\mathrm{cm}(\mathrm{A})$, and $2 \mathrm{~cm}(\mathrm{~B})$, above the squamous epithelial junction (SCJ). Dilated intercellular spaces (DIS) in the erosive esophagus at $5 \mathrm{~cm}(\mathrm{C})$, and $2 \mathrm{~cm}(D)$ of the squamous columnar epithelial junction (SCJ).

than at $2 \mathrm{~cm}(2.72 \pm 1.35 \mu \mathrm{m} v s .1 .71 \pm 0.48 \mu \mathrm{m})$. DIS was less in the erosive and non-erosive varieties, and did not exhibit differences among biopsy sites. A tear in the esophageal mucosa barrier is manifested as DIS; this expression has been identified as an early biological marker of esophageal damage (dilation of $>0.7 \mu \mathrm{m}$ ) (3). Recent studies have demonstrated the presence of DIS as a morphological characteristic of the patient with GERD, independently of whether there was erosive disease or not.

Van Melestein et al. (3) reported that DIS at $2 \mathrm{~cm}$ of SCJ was similar for erosive $(0.80-2.27 \mu \mathrm{m})$ and non-erosive esophagitis $(1.00-2.20 \mu \mathrm{m})(\mathrm{p}=$ not significant [NS]); Caviglia and colleagues (2) also observed no statistically significant differences between both groups with biopsies taken at $5 \mathrm{~cm}$ of the SCJ $(1.41-1.43 \mu \mathrm{m})(\mathrm{p}$ $=\mathrm{NS}$ ); however, the latter authors report that in the control group of asymptomatic patients with negative $\mathrm{pH}$ metry, DIS was $0.42-0.51 \mu \mathrm{m}(\mathrm{p}=0.001)$. In our cases, we observed no differences in the group of patients with $\mathrm{EE}$ and in those in the group with NERD at $2 \mathrm{~cm}$ of 1.68 $\pm 0.45 \mu \mathrm{m} v s .1 .18 \pm 0.51 \mu \mathrm{m}$ and at $5 \mathrm{~cm}$ of $1.97 \pm 0.33$ $\mu \mathrm{m}$ vs. $1.50 \pm 0.40 \mu \mathrm{m}$, respectively) $(\mathrm{p}=\mathrm{NS})$; for the control group, DIS was at $2 \mathrm{~cm}$ of $0.61 \pm 0.20(0.22-0.99)$ and at $5 \mathrm{~cm}$ of $0.70 \pm 0.20(0.12-1.52)(\mathrm{p}=\mathrm{NS})$, similar to that reported by Caviglia et al. of $0.42-0.51 \mu \mathrm{m}$.

Tobey et al. (18) with electronic microscopy report a DIS in EE at $5 \mathrm{~cm}$ of the SCJ of $0.80 \pm 0.12 \mu \mathrm{m}$, for NERD of $1.00 \pm 0.15 \mu \mathrm{m}$, and for the asymptomatic control group, of $0.46 \pm 0.06 \mu \mathrm{m}$. In comparison with these authors, we found more DIS at $5 \mathrm{~cm}$ in EE $(1.97 \pm 0.33$ $\mu \mathrm{m}$ vs. $0.80 \pm 0.12 \mu \mathrm{m})$, and DIS was similar in the control group $(0.46 \pm 0.06 \mu \mathrm{m} v s .0 .70 \pm 0.20 \mu \mathrm{m})$. The majority of our cases were Los Angeles classification grade B. This difference could be related with the difference in magnitude of exposure to acid in the esophagus and chronicity of the disease. Although Caviglia et al. (2) informed that they found no differences between DIS grade and time of acid exposure of the esophagus in patients with NERD.

Calabrese et al. (19) reported with electron microscopy that DIS for reflux acid (EE and NERD) was $2.27 \pm 0.47 \mu \mathrm{m}$ and alkaline reflux was $2.11 \pm 0.23 \mu \mathrm{m}$, while for the control group, this was $0.56 \pm 0.09 \mu \mathrm{m}$. It has been suggested that redistribution of and changes in the cell-protein complex play an important role, and that alterations in the cell's normal metabolism are strongly associated with the presence of gastric or biliary reflux $(10,12)$. We did not carry out distinction of the gastroesophageal reflux (acid or not); however, Calabrese and colleagues (19) found no statistically significant differences between these groups. Our findings show that patients with $\mathrm{BE}$ present greater dilation than those with the erosive and non-erosive varieties, this probably a consequence of the greater chronicity of GERD.

Villanacci et al. (20) included patients with EE and NERD in whom biopsies were analyzed with light microscopy, and proposed DIS as a histological marker for GERD, reporting the presence of DIS at $100 \%$ for EE and at $71.4 \%$ for NERD. This study has limitations because light microscopy did not allow to evaluate DIS grade. The authors found no correlation between basal hyper- 
plasia plus papillary elongation with the degree of tissue lesion. At the same time, Zentilin and colleagues (7) with light microscopy reported the presence of DIS in $30 \%$ of the control group, in $94 \%$ of patients with $\mathrm{EE}$, and in $83 \%$ in patients with NERD. We found DIS to a greater or lesser degree in all cases of GERD.

The dilatation of intercellular spaces is associated with a greater intensity of GERD symptoms by the permeability of hydrogen ions and activate chemosensitive receptors $(2,3,19)$, it explains the symptoms in NERD, but it can not be considered applicable to patients with Barrett's esophagus, because although this entity is part of the spectrum of GERD and has been shown that patients have greater esophageal acid exposure than patients with $\mathrm{EE}$ and NERD $(17,21)$, these have great variability in the intensity of symptoms. In our study, when comparing patients with all varieties of GERD, the DIS was geater in BE and there was no difference in the intensity of symptoms by the Carlsson-Dent questionnaire (EB $7.07 \pm 3.7$, EE $6.55 \pm$ 2.77, NERD $6.8 \pm 4.82, \mathrm{p}=0.82)($ Figs. 3 and 4$)$.

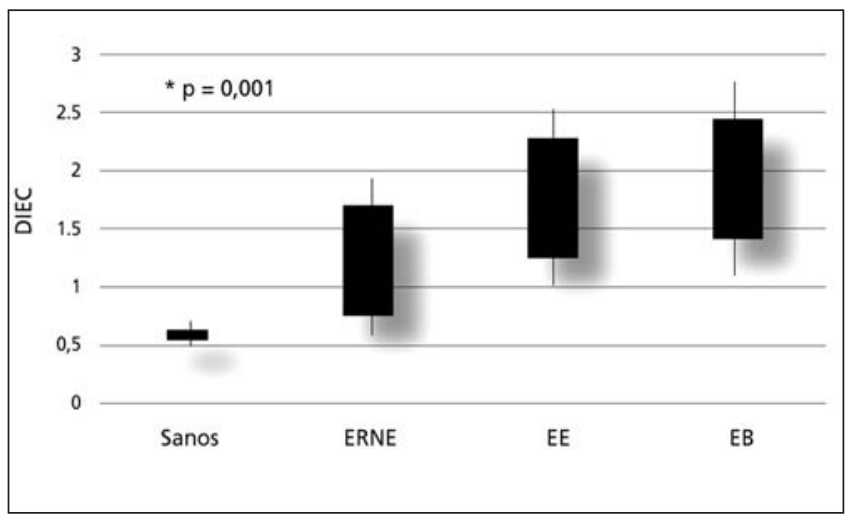

Fig. 3. Dilated intercellular spaces (DIS) at $2 \mathrm{~cm}$ of the squamous columnar epithelial junction (SCJ) in the different gastroesophageal reflux disease (GERD) groups. DIS: dilated intercellular spaces $(\mu \mathrm{m})$; NERD: non-erosive reflux disease; EE: erosive esophagitis; BE: Barrett's esophagus.

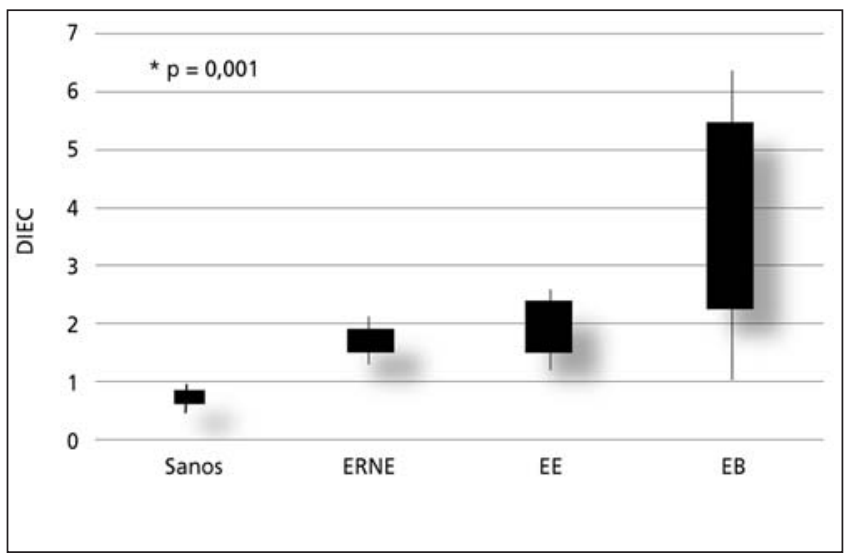

Fig. 4. Dilated intercellular spaces (DIS) at $5 \mathrm{~cm}$ of the squamous columnar junction (SCJ) in the different gastroesophageal reflux disease (GERD) subgroups. DIS: dilated intercellular spaces $(\mu \mathrm{m})$; NERD: nonerosive reflux disease; EE: erosive esophagitis; BE: Barrett's esophagus.
None of the studies referred previously included patients with BE. In the literature, DIS frequency and grade was not been informed in this group of patients who form part of the GERD spectrum. Another important datum is that the site where greatest dilation is observed differs from one study to another, and according to the results published, it is important to determine the most sensitive zone for measuring DIS.

We can conclude exposing that DIS was present in all GERD subtypes (NERD, EE, and BE). We observed more DIS in patients with BE $(2.72 \pm 1.35 \mu \mathrm{m}(5 \mathrm{~cm})>$ $1.71 \pm 0.48 \mu \mathrm{m}(2 \mathrm{~cm})(\mathrm{p}=0.001)$. DIS was less in the erosive and non-erosive varieties and exhibited showed no differences at biopsy sites.

\section{REFERENCES}

1. Kahrilas PJ. GERD pathogenesis, pathophysiology, and clinical manifestations. Cleveland Clinic Journal of Medicine 2003; 70(Supl. 5): S4-19.

2. Caviglia R, Ribolisi M, Gentile M. Dilated intercellular spaces and acid reflux at the distal and proximal oesophagus in patients with non-erosive gastrooesophageal reflux disease. Alimentar Pharm Ther 2007; 25: 629-36.

3. Malenstein H, Farré R, Sifrim D. Esophageal dilated Intercellular spaces (DIS) and nonerosive reflux disease. Am J Gastroenterol 2007; 102: 1-8.

4. Rey E, Álvarez-Sánchez A, Rodríguez-Artalejo F, Moreno C, Almansa C, Díaz-Rubio M. Onset and disappearance rates of gastroesophageal reflux symptoms in the Spanish population, and their impact on quality of life. Rev Esp Enferm Dig 2009; 101: 477-82.

5. Pérez H, Urdiales G, Fernández J, España L, Rodríguez J, Martínez $\mathrm{M}$, et al. Preoperative workup to assess indication for laparoscopic treatment in gastroesophageal reflux disease. Rev Esp Enferm Dig 2008; 100: 405-10.

6. Fass R, Ofman JJ. Gastroesophageal reflux disease. Should we adopt a new conceptual framework? Am J Gastroenterol 2002; 97: 1901-9.

7. Zentilin P, Savarino V, Mastracci L, Spaggiari P, Dulbecco P, Ceppa $\mathrm{P}$, et al. Reassessment of the diagnostic value of histology in patients with GERD, using multiple biopsy sites and an appropriate control group. Am J Gastroenterol 2005; 100: 2299-306.

8. Caviglia R, Rivolsi M, Mariano N. Dilated intercellular spaces of esophageal epithelium in non-erosive reflux disease patients with physiological esophageal acid exposure. Am J Gastreoenterol 2005; 100: 543-8.

9. Tutuian R. Update in the diagnosis of gastroesophageal reflux disease. J Gastrointestin Liver Dis 2006; 15: 243-7.

10. Cappell MS. Clinical presentation, diagnosis, and management of gastroesophageal reflux disease. Med Clin North Am 2005; 89: 24391.

11. Armstrong D. Review article: gastric $\mathrm{pH}$ - the most relevant predictor of benefit in reflux disease? Alimentar Pharm Ther 2004; 20: 19 26.

12. Tack J. Review article: the role of bile and pepsin in the pathophysiology and treatment of gastro-oesophageal reflux disease. Alimentar Pharm Ther 2006; 24: 10-6.

13. Numans ME, De Wit NJ. Reflux symptoms in general practice: diagnostic evaluation of the Carlsson-Dent gastro-oesophageal reflux disease questionnaire. Aliment Pharmacol Ther 2003; 17: 1049-55.

14. Carlsson R, Dent J, Bolling-Sternvald E, Johnsson F, Junghard O, Lauritsen $\mathrm{K}$, et al. The usefulness of a structured questionnaire in the assessment of symptomatic gastroesophageal reflux disease. Scand J Gastroenterol 1998; 33: 1023-9.

15. Cameron AJ, Zinsmeister AR, Ballard DJ, Carney JA. Prevalence of columnar-lined (Barrett's) esophagus. Comparison of population-based clinical and autopsy findings. Gastroenterology 1990; 99: 918-22. 
16. Revicki DA, Wood M, Maton PM, Sorensen S. The impact of gastroesophageal reflux disease on health related quality of life. Am J Med 1998; 104: 252-8.

17. Cappell MS. Clinical presentation, diagnosis, and management of gastroesophageal reflux disease. Med Clin North Am 2005; 89: 243 91.

18. Tobey NA, Carson JL, Alkiek RA, Orlando RC. Dilated intercellular spaces: a morphological feature of acid reflux-damaged human esophageal epithelium. Gastroenterology 1996; 111: 1200.

19. Calabrese C, Fabbri A, Bortolotti M, Cenacchi G, Areni A, Scialpi $\mathrm{C}$, et al. Dilated intercellular spaces as a marker of oesophageal damage: comparative results in gastro-oesophageal reflux disease with or without bile reflux. Aliment Pharmacol Ther 2003; 18 : 525-32.

20. Villanacci V, Grigolato PG, Cestari R, Missale G, Cengia G, Klersy $\mathrm{C}$, et al. Dilated intercellular spaces as markers of reflux disease: histology, semiquantitative score and morphometry upon light microscopy. Digestion 2001; 64: 1-8.

21. Shapiro M, Green C, Faybush EM, Esquivel RF, Fass R. The extent of oesophageal acid exposure overlap among the different gastro-oesophageal reflux disease groups. Aliment Pharmacol Ther 2006; 23(2): $321-9$ 